\title{
DAMPAK PENUTUPAN PERLINTASAN KERETA API LEMPUYANGAN TERHADAP RUAS JALAN DI SEKITARNYA.
}

\author{
Prima Juanita Romadhona ${ }^{1}$, Raditya Wisnumurti ${ }^{1}$ \\ 1. Program Studi Teknik Sipil, Fakultas Teknik Sipil dan Perencanaan, Universitas Islam Indonesia
}

\begin{abstract}
Abstrak
Rencana pemerintah dalam meningkatkan pelayanan keselamatan transportasi kereta api berujung pada penutupan secara permanen perlintasan kereta api termasuk perlintasan Lempuyangan. Maka dari itu, dibutuhkan penelitian lalu lintas untuk mengetahui kinerja ruas jalan di sekitar lingkup perlintasan tersebut sehingga dapat mengetahui tingkat pelayanan ruas jalan serta memberikan permodelan lalu lintas akibat penutupan perlintasan kereta api Lempuyangan. Penelitian ini dilakukan dengan metode survei langsung lapangan Yogyakarta untuk mendapatkan data yang diperlukan. Analisis pada penelitian ini mencakup analisis tingkat pelayanan ruas Jalan Layang Dr.Sutomo dan Simpang Bawah Jalan Layang tersebut. Dalam analisis tingkat pelayanan ruas jalan digunakan Manual Kapasitas Jalan Indonesia 1997 yang nantinya juga akan menggunakan aplikasi permodelan VISSIM untuk memodelkan pada kondisi eksisting dan pasca penutupan perlintasan kereta api. Hasil dari penelitian ini didapatkan bahwa nilai derajat kejenuhan pada semua ruas jalan di simpang bawah flyover cenderung mengalami peningkatan yang berarti penurunan kinerja ruas jalan kecuali pada ruas jalan flyover Dr. Sutomo. Sedangkan untuk nilai kecepatan, kecenderungan peningkatan terjadi pada ruas Jl. Lempuyangan, Jl. Argolubang dan Jl. Dr. Sutomo. Namun terjadi penurunan pada ruas Jl. Flyover Dr. Sutomo. Selain itu, Jl. Wahidin Sudirohusodo tidak mengalami perbedaan karena tidak ada kendaraan yang melintas akibat penutupan perlintasan kereta api
\end{abstract}

Kata kunci: penutupan pelintasan kereta api; VISSIM; ruas jalan.

\begin{abstract}
[Title: The Impact of Lempuyangan Level Crossing Permanent Closure At Surround Roads ] The government's plan to improve railway transportation safety service has led to a permanent closure for level crossings including the Lempuyangan level crossing. Therefore, traffic research would be needed to determine the level of service of roads and provide modeling traffic on the impact of the Lempuyangan level crossing closure. This research was conducted by a direct field survey method to obtain the data. The analysis in this study includes an analysis of the service level of the Dr. Sutomo Flyover and the junction below of the Flyover. In the analysis of the level of service of the road using the 1997 Indonesia Road Capacity Manual, it would be also necessary to use the VISSIM modeling application to give the model of existing conditions and post level crossing closure. The results of this study found that the degree of saturation on all road segments at the flyover lower junction experienced an increasing trend which means the decreased performance of road segment except on Dr. Sutomo Flyover road segment. As for the speed value, the increasing trend was in the Jl. Lempuyangan, Jl. Argolubang, and Jl. Dr. Sutomo. But there was a decrease in the section of Jl. Dr. Flyover Sutomo. In addition, Jl. Wahidin Sudirohusodo would be a not experienced difference because there would be no vehicles passing due to the closing of the railway crossing.
\end{abstract}

Keywords: level crossing closure;VISSIM; roadsegment

\section{Pendahuluan}

$\left.{ }^{*}\right)$ Penulis Korespondensi.
E-mail: prima_dhona@uii.ac.id
Sarana transportasi kereta api hampir selalu membentuk pertemuan dengan sarana transportasi jalan raya. Pertemuan inilah yang disebut dengan perlintasan sebidang. Perlintasan sebidang memiliki tingkat resiko yang tinggi dikarenakan mengganggu keselamatan 
perjalanan kereta api. Perlintasan kereta api Lempuyangan menjadi salah satu target penutupan oleh Kementrian Perhubungan sebagai salah satu upaya untuk mengurangi kecelakaan kereta api. Dalam artikel berita yang ditulis Prasetyo (2018), Kepala Bidang Lalu Lintas Golkari Made Yulianto menyatakan bahwa visi rasio pada ruas Jalan Dr.Sutomo meningkat hingga 0,9 sehingga kondisinya sangat padat. Sehingga diperlukannya suatu permodelan lalu lintas yang nantinya berguna untuk mengetahui kinerja dari beberapa ruas jalan tersebut setelah dilakukannya penutupan perlintasan kereta api Lempuyangan. Dalam menganalisis kinerja ruas jalan menggunakan panduan dari Manual Kapasitas Jalan Indonesia (MKJI) 1997. Selain itu penelitian ini juga memilih untuk menganalisis kinerja suatu ruas jalan menggunakan software VISSIM. VISSIM merupakan aplikasi yang dikhususkan pada bidang permodelan transportasi ditujukan memudahkan dalam memberikan permodelan sistem transportasi perkotaan, metropolitan, dan regional sehingga mampu mempresentasikan kondisi sebenarnya yang terjadi di lapangan. Rumusan masalah dalam penelitian ini mencari tahu berapa nilai kinerja semua ruas jalan yang terdapat pada simpang bawah flyover dan Jl. Flyover pada kondisi eksisting dan kondisi setelah penutupan perlintasan kereta api yang nantinya akan dibandingkan. Tujuan penelitian ini adalah untuk mengetahui kinerja ruas jalan pada 2 kondisi tersebut dan mendapatkan permodelan lalu lintas nantinya.

Penelitian yang dilakukan Widodo pada tahun 2012 melakukan kajian penutupan perlintasan sebidang di Jalan KH. Mas Mansyur dan Jalan Abdul Syafi ie Provinsi DKI Jakarta, yang bertujuan untuk mendapatkan biaya operasional kendaraan sebelum dan sesudah penutupan perlintasan sebidang. Hasilnya terjadi kenaikan biaya operasional kendaraan pada setiap ruas jalannya. Hadis dan Sumarsono (2013) dalam penelitiannya di perlintasan kereta api di sekitar Stasiun Jebres, Surakarta, menggunakan metode analisis linier regresi yang bertujuan untuk menganalisis hubungan tundaan dan panjang antrean terhadap konsumsi BBM akibat penutupan perlintasan kereta api pada Jl. Urip Sumoharjo dan Jl. Hos Cokroaminoto. Penelitian ini menghasilkan jumlah konsumsi BBM (liter/smp) ratarata berdasarkan nilai tundaan dan panjang antrean pada setiap ruas jalan tersebut. Penelitian yang dilakukan oleh Mulyono (2006) menganalisis tentang seberapa lama waktu delay, panjang antrean, dan besar kerugian saat terjadi penutupan palang kereta api. Dengan metode perhitungan menggunakan MKJI, didapatkan hasil tundaan rata-rata sebesar 15 detik, panjang antrean sebelah utara $21 \mathrm{smp}$ dan sebelah selatan $19 \mathrm{smp}$, dan besar kerugian pengguna jalan $\mathrm{Rp}$ 2.865.250.000,-/tahun. Penelitian yang dilakukan oleh Yusyadiputra dkk. (2014) tentang pengaruh penutupan perlintasan kereta api yang berpengaruh terhadap kinerja lalu lintas jalan raya di segmen Jl. Kaligawe Semarang dan Jl. Kaliwungu
Kendal. Dengan metode analisis dan pengolahan data menggunakan MKJI 1997 dan juga metode shockwave, penelitian ini bertujuan mengevaluasi simpang perlintasan sebidang dan menganalisa kinerja lalu lintas jalan raya akibat penutupan perlintasan kereta api pada kondisi eksisting. Penelitian ini menghasilkan nilai ds pada Jl. Kaligawe sebesar 0,4 dimana jalan tersebut tidak mampu menampung lalu lintas, dan nilai ds pada Jl. Kaliwungu sebesar 0,75 dimana jalan tersebut tidak mampu menampung lalu lintas saat terjadi penutupan palang pintu kereta api pada perlintasan sebidang tersebut.

\section{Persyaratan Perlintasan Sebidang}

Direktorat Jenderal Perhubungan Darat dalam Peraturan Dirjen Perhubungan Darat (2005) menyebutkan bahwa perpotongan antara jalur kereta api dengan jalan disebut perlintasan sebidang. Bahkan perlintasan sebidang mempunyai persyaratan yaitu sebagai berikut.

a) Permukaan jalan harus satu level dengan kepala rel dengan toleransi $0,5 \mathrm{~cm}$.

b) Terdapat permukaan datar sepanjang $60 \mathrm{~cm}$ diukur dari sisi terluar jalan rel.

c) Maksimum gradien untuk dilewati kendaraan dihitung dari titik tertinggi dikepala rel adalah:

i. $2 \%$ diukur dari sisi terluar permukaan datar sebagaimana dimaksud pada huruf $\mathrm{b}$ untuk jarak 9,4 meter.

ii. $10 \%$ untuk 10 meter berikutnya dihitung dari titik terluar butir, sebagai gradien peralihan

d) Lebar perlintasan untuk satu jalur jalan maksimum 7 meter

e) Sudut perpotongan antara jalan rel dengan jalan harus $90^{\circ}$ dan panjang jalan yang lurus minimal 150 meter dari as jalan rel.

\section{Kinerja Ruas Jalan Perkotaan.}

Penelitian ini menggunakan analisis perhitungan kinerja ruas jalan dalam kondisi eksisting maupun pasca penutupan dengan mencari nilai derajat kejenuhan sesuai dengan aturan jalan perkotaan pada Manual Kapasitas Jalan Indonesia. Nilai DS menunjukkan apakah segmen jalan tersebut mempunyai masalah kapasitas atau tidak.

Keterangan,

$$
\mathrm{DS}=\mathrm{Q} / \mathrm{C}
$$

$\mathrm{DS}=$ Derajat Kejenuhan

$\mathrm{Q} \quad=$ Arus Lalu Lintas (smp/jam)

$\mathrm{C}=$ Kapasitas (smp/jam) dimana,

Perhitungan dasar kapasitas adalah sebagai berikut. $\mathrm{C}=\mathrm{Co} \times \mathrm{FCw} \times \mathrm{FCsp} \times \mathrm{FCsf} \times \mathrm{FCcs}$

Keterangan:

$\mathrm{C} \quad=$ Kapasitas (smp/jam)

$\mathrm{Co} \quad=$ Faktor Penyesuaian Lebar Jalan

FCsp = Faktor Penyesuaian Pemisahan Arah (hanya jalan tak terbagi) 
$\begin{aligned} & \text { FCsf }= \text { Faktor Penyesuaian Hambatan Samping dan } \\ & \text { Bahu Jalan/Kereb } \\ & \text { FCcs }=\text { Faktor Penyesuaian Kota }\end{aligned}$

\section{Metode Pemilihan Rute}

Selain perhitungan analisis derajat kejenuhan, penelitian ini juga melakukan analisis pembebanan perjalanan (Trip Assignment) atau pemilihan rute. Tamin (2000) menjabarkan metode pembebanan perjalnan yang terbagi menjadi berikut.

\subsection{All or Nothing Assignment}

Pada metode All or Nothing semua pengguna akan memilih rute terpendek guna meminimumkan hambatan transportasi berupa jarak, waktu dan biaya. Tidak ada pengendara yang memilih rute lain selain rute dengan hambatan transportasi yang paling sedikit tersebut. Dengan begitu, dapat disimpulkan bahwa pengendara akan memilih rute yang sama. Kemacetan tidak menjadi pertimbangan dalam penggunaan metode ini.

\subsection{Equilibrium Assignment}

Wardrop, J.G. (1952), menguraikan bahwa terdapat dua perilaku yang mendorong pengemudi untuk memilih rute dimana perilaku tersebut dinamakan "Prinsip Wardrop Equilibrium".

a. Kondisi Equilibrium : tidak ada pengguna jalan yang dapat mengubah rutenya untuk mendapatkan biaya perjalanan yang lebih murah, karena semua rute yang tidak digunakan mempunyai biaya perjalanan yang sama atau lebih besar dari pada rute yang dilaluinya sekarang.

b. Kondisi optimum : total biaya sistem yang terjadi adalah minimum.

4.3 Pembebanan Berpeluang

Metode ini mengasumsikan pengguna jalan menggunakan beberapa faktor rute dalam pemilihan rutenya dengan meminimunkan hambatan transportasi. Contohnya faktor yang tidak dapat dikuantifikasi seperti rute yang aman dan rute yang panoramanya indah. Dalm hal ini, pengendara memperhatikan faktor lain selain jarak, waktu tempuh, dan biaya yaitu misalnya rute yang telah dikenal atau dianggap aman.

4.4 Stochastic Traffic Assignment

Metode ini dipakai berdasarkan pada asumsi bahwa para pelaku perjalanan yang akan menggunakan rute alternatif, tidak dipengaruhi oleh kondisi kemacetan pada ruas jalan. Sehingga pengemudi mempunyai presepsi masing-masing terhadap rute terbaik yang akan digunakan.

\section{Tingkat Pelayanan Jalan.}

Penelitian ini bertujuan untuk mencari tingkat pelayanan jalan berdasarkan kecepatan kendaraan. Menurut Peraturan Menteri Perhubungan Tahun 2015, tingkat pelayanan pada ruas jalan diklasifikasikan sebagai berikut.

1.Tingkat pelayanan A dengan kondisi,

a. arus bebas volume lalu lintas rendah dan kecepatan sekurang-kurangnya $80 \mathrm{~km} / \mathrm{jam}$

b. kepadatan lalu lintas sangat rendah

c. pengemudi dapat mempertahankan kecepatan yang diinginkan tanpa atau sedikit tundaan

2. Tingkat pelayanan B dengan kondisi,

a. arus stabil dengan volume lalu lintas sedang dan kecepatan sekurang-kurangnya $70 \mathrm{~km} / \mathrm{jam}$

b. kepadatan lalu lintas rendah, hambatan internal lalu lintas belum mempengaruhi kecepatan.

c. pengemudi masih punya cukup kebebasan untuk memilih kecepatannya dan lajur jalan yang digunakan.

3. Tingkat pelayanan $\mathrm{C}$ dengan kondisi,

a. arus stabil tetapi pergerakan lalu lintas yang lebih tinggi dengan kecepatan sekurangkurangnya $60 \mathrm{~km} / \mathrm{jam}$

b. kepadatan lalu lintas sedang karena hambatan internal lalu lintas meningkat

c. pengemudi memiliki keterbatasan dalam memilih kecepatan, pindah jalur atau mendahului.

4. Tingkat pelayanan D dengan kondisi,

a. arus mendekati tidak stabil dengan volume lalu lintas tinggi dan kecepatan sekurang-kurangnya $50 \mathrm{~km} / \mathrm{jam}$

b. masih ditolerir namun sangat terpengaruh oleh perubahan kondisi arus

c. kepadatan lalu lintas sedang namun fluktuasi lalu lintas dan hambatan temporer dapat me nyebabkan penurunan kecepatan yang besar.

d. pengemudi memiliki keterbatasan dalam memilih kecepatan, pindah jalur atau mendahului.

5. Tingkat pelayanan E dengan kondisi,

a. arus mendekati tidak stabil dengan volume mendekati kapasitas jalan dan kecepatan sekurang-kurangnya $30 \mathrm{~km} / \mathrm{jam}$ pada jalan antar kota dan sekurang-kurangnya $10 \mathrm{~km} / \mathrm{jam}$ pada jalan perkotaan

b. kepadatan lalu lintas tinggi karena hambatan internal lalu lintas tinggi

c. pengemudi mulai merasakan kemacetan durasi pendek.

6. Tingkat pelayanan $\mathrm{F}$ dengan kondisi,

a. arus tertahan dan terjadi antrean kendaraan yang panjang dengan kecepatan kurang dari 30 $\mathrm{km} / \mathrm{jam}$

b. kepadatan lalu lintas sangat tinggi dan volume rendah serta terjadi kemacetan untuk durasi yang cukup lama

c. dalam keadaan antrean, kecepatan maupun volume turun sampai 0 (nol). 


\section{PTV VISSIM}

Dalam permodelan lalu lintas digunakan software VISSIM. VISSIM menjadi perangkat lunak yang berguna untuk evaluasi berbagai langkah alternatif berdasarkan langkah-langkah rekayasa transportasi dan perencanaan efektivitas. VISSIM sendiri merupakan kependekan dari "Verkehr In Städten Simulationsmodell" yaitu bahasa Jerman dari "Simulasi Permodelan Lalu Lintas Dalam Kota". PTV VISSIM dikembangkan oleh Planing Transport Verkehr AG di Karlsruhe, Jerman pada tahun 1992 (Planung Transport Verkehr AG, 2017). Dalam proses validasi data, digunakan rumus statistik Geoffrey E. Havers

$$
\sqrt{\frac{(q \text { simulated }-q \text { observed })^{2}}{0,5 \times(q \text { simulated }+ \text { qobserved })}}
$$

Dimana,

$Q$ simulated $=$ volume lalu lintas hasil output VISSIM $Q$ observed $=$ volume lalu lintas hasil survei lapangan Sedangkan nilai error untuk menentukan diterima atau tidaknya hasil validasi sebagai berikut.

Tabel 1. Kriteria Hasil Uji Statistik

\begin{tabular}{cc}
\hline GEH $<\mathbf{5 , 0}$ & Diterima \\
\hline $5,0 \leq \mathrm{GEH} \leq 10$ & $\begin{array}{c}\text { Peringatan kemungkinan model } \\
\text { error atau data buruk }\end{array}$ \\
\hline $\mathrm{GEH}>10$ & ditolak \\
\hline
\end{tabular}

\section{Hasil dan Pembahasan}

Nilai driving behaviour pada saat kendaraan berhenti didapatkan jarak minimum samping kiri-kanan antar pengemudi sebesar $0,9 \mathrm{~m}$ dan rerata $1,01 \mathrm{~m}$. Sedangkan, jarak minimum depan-belakang sebesar 0,13 $\mathrm{m}$ dan rerata $0,86 \mathrm{~m}$. Sedangkan driving behaviour pada saat kendaraan melintas didapatkan jarak minimum samping kiri-kanan antar pengemudi sebesar $0,72 \mathrm{~m}$ dan rerata $2 \mathrm{~m}$. Sedangkan, jarak minimum depan-belakang sebesar $0,6 \mathrm{~m}$ dan rerata $1,63 \mathrm{~m}$.

Tabel 2.Rekapitulasi Data Kecepatan

Kendaraan

\begin{tabular}{ccccccc}
\hline \multirow{2}{*}{ Ruas Jalan } & \multicolumn{2}{c}{ Dr. Sutomo (flyover) } & \multicolumn{2}{c}{ Lempuyangan } & \multicolumn{2}{c}{ Argolubang } \\
\hline \multirow{2}{*}{$\begin{array}{c}\text { Jenis } \\
\text { Kendaraan }\end{array}$} & \multicolumn{2}{c}{ Kecepatan $(\mathbf{k m} /$ jam) } & \multicolumn{2}{c}{ Kecepatan $(\mathbf{k m} /$ jam) } & \multicolumn{2}{c}{ Kecepatan $(\mathbf{k m} / \mathrm{jam})$} \\
\cline { 2 - 7 } & Terendah & Tertinggi & Terendah & Tertinggi & Terendah & Tertinggi \\
\hline MC & 29,016 & 54,144 & 20,16 & 59 & 19,89 & 60,516 \\
LV & 28,332 & 45 & 13,32 & 42,84 & 25,344 & 39,78 \\
HV & 24,64 & 39,99 & 21,2 & 40 & 21,2 & 40 \\
\hline
\end{tabular}

Didapatkan data kecepatan kendaraan tertinggi dan terendah pada jam puncak di 3 ruas jalan yaitu $\mathrm{Jl}$. Flyover, Jl. Lempuyangan, Jl. Argolubang.
Tabel 3.Rekapitulasi Data Kecepatan Kendaraan

\begin{tabular}{ccccc}
\hline \multirow{2}{*}{ Ruas Jalan } & \multicolumn{2}{c}{ Wahidin Sudirohusodo } & \multicolumn{2}{c}{ Dr. Sutomo } \\
\hline \multirow{2}{*}{ Jenis Kendaraan } & \multicolumn{2}{c}{ Kecepatan $(\mathbf{k m} / \mathbf{j a m})$} & \multicolumn{2}{c}{ Kecepatan $(\mathbf{k m} / \mathbf{j a m})$} \\
\cline { 2 - 5 } & Terendah & Tertinggi & Terendah & Tertinggi \\
\hline MC & 23,004 & 49,68 & 23,292 & 38,916 \\
LV & 25,992 & 46,152 & 21,636 & 32,292 \\
\hline
\end{tabular}

Didapatkan data kecepatan kendaraan tertinggi dan terendah pada jam puncak di 2 ruas jalan yaitu Jl. Wahidin Sudirohusodo, Jl. Dr. Sutomo.

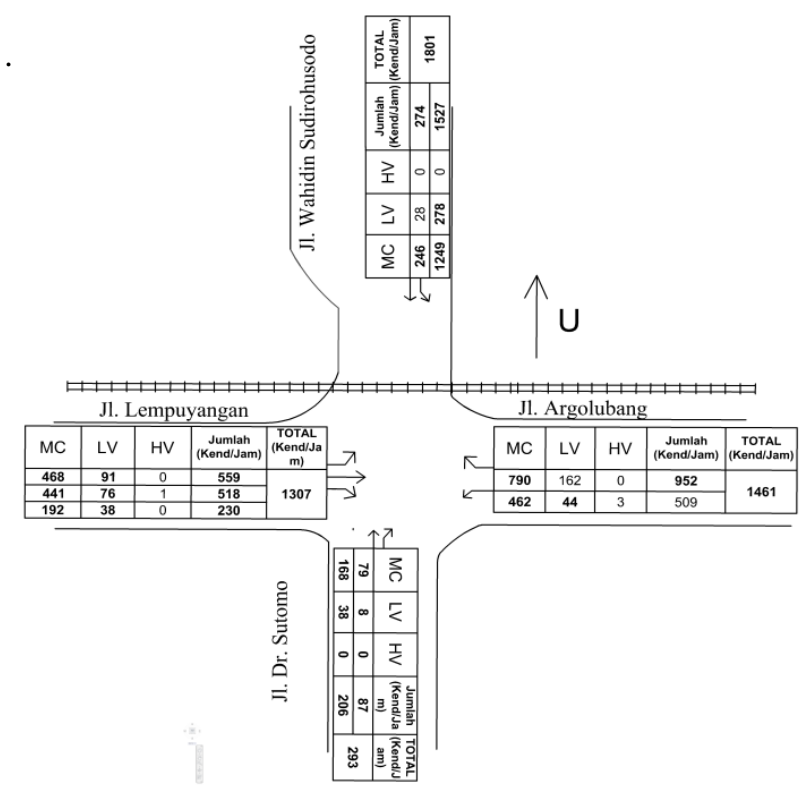

Gambar 1. Arus Simpang Bawah Flyover

(Sumber: Dishub Pemkot Yogyakarta 2018)

Setelah mengumpulkan data-data tersebut, dilakukan skenario pengalihan arus lalu lintas. Metode all or nothing digunakan pada simpang 3 Utara Flyover, sehingga nantinya semua kendaraan dari simpang 3 Utara Flyover yang akan menuju Selatan akan melalui ruas Jl. Flyover. Begitupun juga sebaliknya kendaraan yang berasal dari arah Selatan yang akan menuju arah Utara. Pada simpang 3 tak bersinyal LempuyanganHayamWuruk digunakan metode pembebanan berpeluang dengan asumsi dimana pengendara akan memilih rute selain faktor rute terpendek namun juga faktor bahwa pengendara sudah mengenal rute yang ada dan faktor kenyamanan. Metode tersebut juga berlaku pada simpang Brimob. Sehingga, distribusi arus lalu lintas pada simpang bawah flyover menjadi seperti Gambar 2 sebagai berikut. 


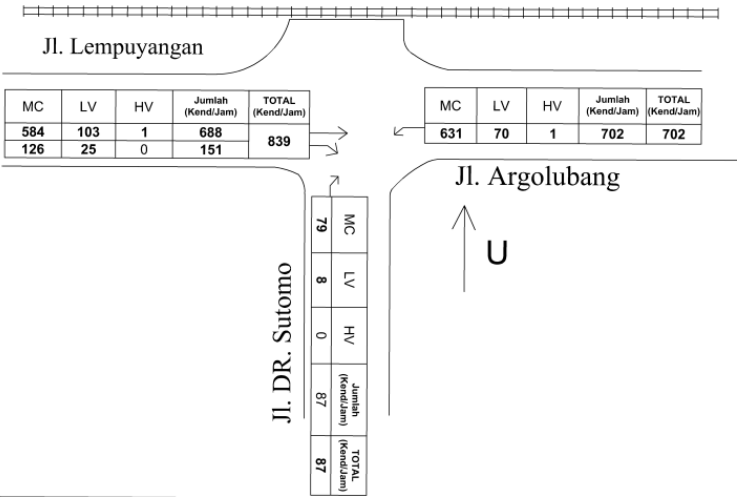

Gambar 2. Arus Lalu Lintas Bawah Flyover Pasca Penutupan.

Setelah dilakukan skenario pengalihan arus lalu lintas, langkah berikutnya adalah perhitungan nilai derajat kejenuhan (DS). Nilai DS pada setiap ruas jalan pada simpang bawah flyover pada kondisi eksisting dan kondisi pasca penutupan dapat dilihat pada Tabel 4 sebagai berikut.

Tabel 4. Hasil Perhitungan Derajat Kejenuhan

\begin{tabular}{cccc}
\hline Lokasi & Eksisting & $\begin{array}{c}\text { Pasca } \\
\text { Penutupan }\end{array}$ & Selisih \\
\hline $\begin{array}{c}\text { Jl. } \\
\text { Lempuyangan }\end{array}$ & 0,57 & 0,40 & $-36 \%$ \\
$\begin{array}{c}\text { J1. Argolubang } \\
\text { Jl. Wahidin }\end{array}$ & 0,63 & 0,19 & $-60 \%$ \\
$\begin{array}{c}\text { Sudirohusodo } \\
\text { Jl. Dr. Sutomo } \\
\text { Flyover Dr. } \\
\text { Sutomo }\end{array}$ & 1,39 & - & - \\
\hline
\end{tabular}

Nilai derajat kejenuhan pada ruas Jl. Lempuyangan, Jl. Argolubang dan Jl. Dr. Sutomo mengalami penurunan. Sedangkan pada Jl. Flyover mengalami kenaikan. Setelah diketahui nilai derajat kejenuhan, langkah berikutnya adalah membuat simulasi lalu lintas berdasarkan datadata yang ada menggunakan software VISSIM. Analisis dilakukan dengan membuat permodelan pada setiap kondisi yaitu kondisi eksisting dan pasca penutupan. Hasil running VISSIM akan dikalibrasi dengan nilai randomseed yang berbeda selama 5 kali proses running. Setelah itu dilakukan validasi data sehingga dapat sesuai dengan kondisi di lapangan dengan rumus statistik Geoffrey E Havers (GEH) didapatkan hasil validasi sebagai berikut.
Tabel 5. Hasil Perhitungan Derajat Kejenuhan

\begin{tabular}{cccc}
\hline qEksisting & $\begin{array}{c}\text { qOutput } \\
\text { VISSIM }\end{array}$ & Hasil & Validasi \\
\hline 1778 & 1784,2 & 0,15 & diterima \\
1536 & 1473,2 & 1,62 & diterima \\
1159 & 1139,6 & 0,57 & diterima \\
948 & 946,8 & 0,04 & diterima \\
1547 & 1378 & 4,42 & diterima \\
1413 & 1401,8 & 0,3 & diterima \\
2745 & 2750,8 & 0,11 & diterima \\
1492 & 1467,8 & 0,63 & diterima \\
2988 & 2826,8 & 3 & diterima \\
\hline
\end{tabular}

Semua hasil output VISSIM dinyatakan diterima karena semua nilainya dibawah 5. Dari VISSIM tersebut didapatkan hasil kecepatan kendaraan pada 2 kondisi tersebut.

Tabel 6. Kecepatan Kendaraan Hasil VISSIM

\begin{tabular}{cccc}
\hline Lokasi & Eksisting & $\begin{array}{c}\text { Pasca } \\
\text { Penutupan }\end{array}$ & Selisih \\
\hline J1.Lempuyangan & 29,57 & 31,12 & $4,98 \%$ \\
Jl. Argolubang & 31,45 & 32,46 & $3,11 \%$ \\
Jl. Wahidin & 27,45 & - & - \\
Sosrohusodo & 39,73 & 40,28 & $1,38 \%$ \\
J1. Dr. Sutomo & 33,32 & 18,93 & $-43,19 \%$ \\
$\begin{array}{c}\text { Flyover Dr. } \\
\text { Sutomo }\end{array}$ & & &
\end{tabular}

Didapatkan kecepatan kendaraan pada ruas Jl. Lempuyangan dan Jl. Argolubang mengalami kenaikan dan Jl. Dr Sutomo dan Flyover mengalami penurunan. Sehingga didapatkan nilai level of service pada semua ruas jalan tersebut.

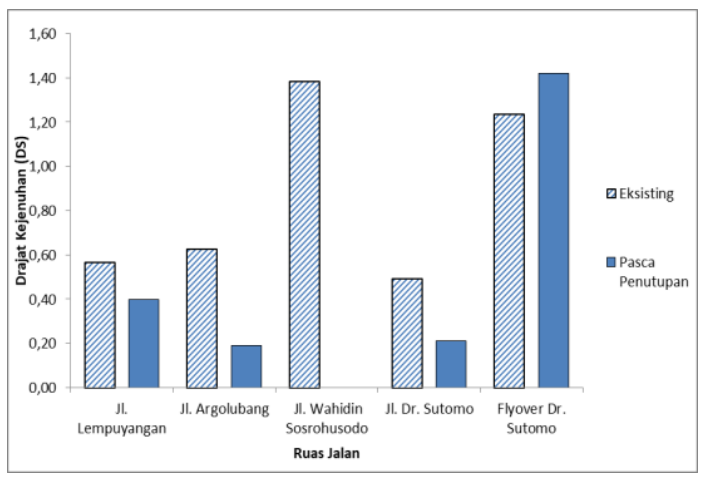

Gambar 3. Grafik Perbandingan Nilai DS 
Grafik di atas menunjukkan bahwa semua ruas jalan pada simpang bawah flyover mengalami penurunan nilai derajat kejenuhan saat kondisi pasca penutupan kecuali pada Jl. Flyover Dr. Sutomo yang mengalami kenaikan nilai derajat kejenuhan. Sedangkan, Jl. Wahidin Sosrohusodo tidak memiliki pembanding.

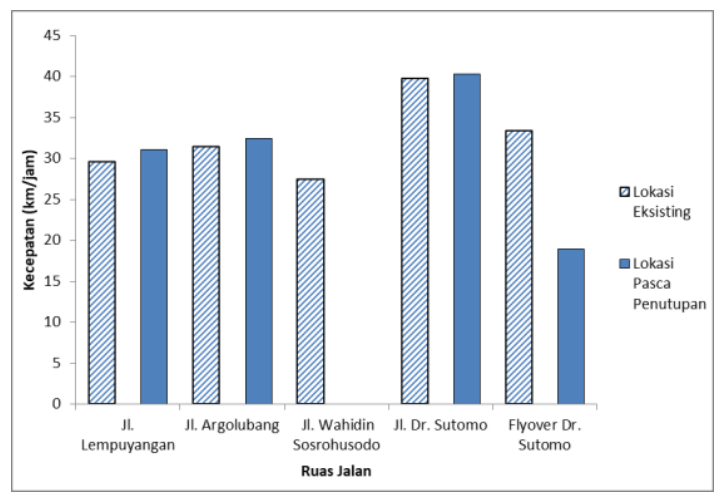

Gambar 4. Grafik Perbandingan Kecepatan Kendaraan

Grafik di atas menunjukkan kecepatan kendaraan pada ruas Jl. Lempuyangan, Jl. Argolubang, Jl. Dr. Sutomo mengalami kenaikan sedangkan Jl. Flyover mengalami penurunan.

Tabel 7. Level of Service Ruas Jalan Simpang Bawah Flyover

\begin{tabular}{cc}
\hline Lokasi & $\begin{array}{c}\text { Level of } \\
\text { Service }\end{array}$ \\
\hline Jl. Lempuyangan & $\mathrm{E}$ \\
J1. Argolubang & $\mathrm{E}$ \\
Jl. Wahidin Sudirohusodo & $\mathrm{E}$ \\
Jl. Dr. Sutomo & $\mathrm{E}$ \\
Flyover Dr. Sutomo & $\mathrm{E}$ \\
\hline
\end{tabular}

Dari tabel diatas didapatkan semua ruas jalan di simpang bawah flyover Lempuyangan mempunyai tingkat pelayanan jalan ( Level of Service ) "E".

\section{Kesimpulan}

Nilai DS pada ruas Jl. Lempuyangan, Jl. Argolubang dan Jl. Dr. Sutomo mengalami penurunan, yang berarti peningkatan kinerja ruas jalan masingmasing sebesar 29,49\%, 69,75\% dan 57,40\%. Jl. Flyover Dr. Sutomo mengalami kenaikan nilai DS yang berarti penurunan kinerja ruas jalan sebesar 14,92\%. Sedangkan, Jl. Wahidin Sudirohusodo tidak mempunyai pembanding karena diasumsikan setelah penutupan perlintasan kereta api tidak ada kendaraan yang melintas pada ruas jalan tersebut. Sedangkan, nilai kecepatan pada ruas Jl. Lempuyangan, Jl. Argolubang dan Jl. Dr. Sutomo mengalami kenaikan sebesar 4,98 \%, 3,11\% dan 1,38\%.
Jl. Flyover Dr. Sutomo mengalami penurunan nilai kecepatan yang sebesar 43,19\%. Sehingga, tingkat pelayanan jalan pada semua ruas pada simpang bawah flyover tersebut adalah E, yaitu arus mendekati tidak stabil dengan kecepatan sekurang-kurangnya $10 \mathrm{~km} / \mathrm{jam}$ pada jalan perkotaan.

\section{Daftar Pustaka}

Dinas Perhubungan Pemerintah Kota Yogyakarta.(2018). Survei Normalisasi Simpang.

Direktorat Jenderal Bina Marga. (1997). Manual Kapasitas Jalan Indonesia (MKJI).

Direktorat Jenderal Perhubungan Darat. (2005). Peraturan Direktur Jenderal Perhubungan Darat Nomor SK.770/KA.401/DRJD/2005 tentang Pedoman Teknis Perlintasan Sebidang Antara Jalan dengan Jalur Kereta Api. 1-53.

Hadis, C. S., \& Sumarsono, A. (2013). Hubungan Tundaan dan Panjang Antrian terhadap Konsumsi Bahan Bakar Akibat Penutupan Pintu Perlintasan Kereta Api (Studi Kasus pada Perlintasan Kereta Api di Surakarta). Matriks Teknik Sipil, 1(2), 3845. Retrieved from http:matriks.sipi.ft.uns.ac.id/index.php/MaTekSi/ar ticle/view/47

Menteri Perhubungan. (2015). PM No.96 Tahun 2015 Tentang Pedoman Pelaksanaan Kegiatan Manajemen dan Rekayasa Lalulintas.

Mulyono,G.S. (2006). ANALISIS LALULINTAS PERTEMUAN JALAN RAYA DENGAN LINTASAN. 2(1), 42-45.

Planung Transport Verkehr AG. (2017). VISSIM 9.0-11 User Manual.

Prasetyo. (2018). BAHAYA, PERLINTASAN KERETA BAWAH FLYOVER LEMPUYANGAN BELUM DITUTUP. Retrieved from https://www.jawapos.com/jpg $=$ today/02/11/2017/bahaya-perlintasan-keretabawah-flyover-lempuyangan.

Tamin, O. Z. (2000). Perencanaan dan Pemodelan Transportasi Penerbit ITB EDISI KEDUA EDISI KEDUA.

Wardrop, J.G. (1952). Some theoretical aspects of road traffic research. Proceedings of the Institute of Civil Engineers Part 2.

Widodo, A. P. (2007). Kajian Penutupan Perlintasan Sebidang antara Jalan Kereta Api dengan Jalan Raya pada lokasi Jalan KH . Mas Mansyur dan Jalan Abdul Syafi ' ie Provinsi Daerah Khusus Ibukota Jakarta. 1-40.

Yusyadiputra, M., Hermawanto, R., Pudjianto, B., \& Yulipriyono, E. (2014). Pengaruh Penutupan Pintu Perlintasan Jalan Rel Terhadap Kinerja Lalu Lintas Jalan Raya Di Perlintasan Kaligawe Semarang Dan Kaliwungu Kendal. Jurnal Karya Teknik Sipil, 3(3), 723-735. 
